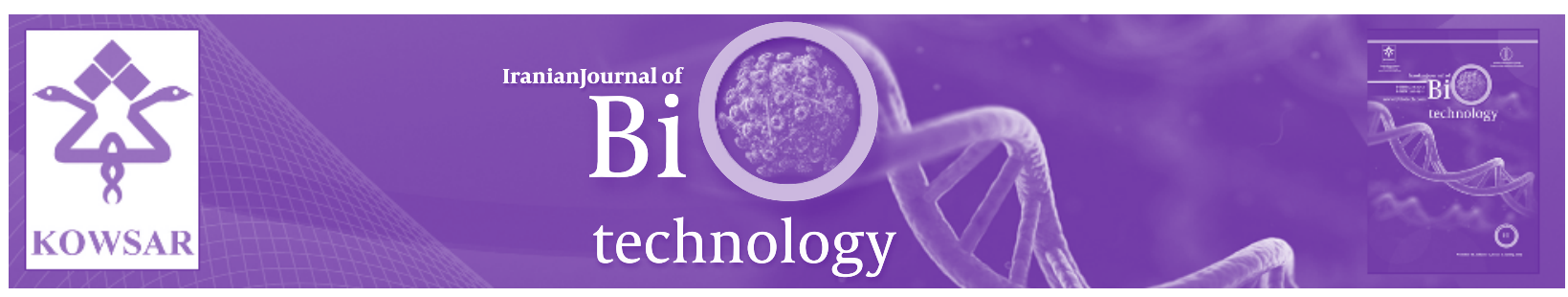

\title{
Genomics and Olive Oil: Past and Current Challenges of Olive Oil Adultera- tion
}

\author{
Zohreh Rabiei ${ }^{1, *}$ \\ ${ }^{1}$ National Institute of Genetic Engineering and Biotechnology, Tehran, IR Iran \\ ${ }^{*}$ Corresponding author: Zohreh Rabiei, National Institute of Genetic Engineering and Biotechnology, Tehran, IR Iran. Tel: +98- 2144580407, Fax: +98- \\ 2144580399, E-mail: rabiei@nigeb.ac.ir.
}

Keywords: Genetic Traceability; Molecular Fingerprinting; Olive Oil Adulteration

For many years, assessment of olive oil quality and its authenticity confirmation has been of great importance to guarantee olive oil safety in compliance with legislations. These include the investigation of olive oil purity and quality by analyzing several parameters such as fatty acid composition, sterols, phenolic compounds, triacylglycerol and etc, through performing conventional and advanced hyphenated techniques (1). This issue still has key importance for research institutions, industries, and export/import agencies although it bears numerous complications; for example the composition of extra virgin olive oils is the result of complex interactions among olive varieties, environmental conditions, fruit ripening, and oil extraction technology (2) which cause fluctuating results for the oil from the same cultivar grown in different locations. The International Olive Council (IOC) (the International Olive oil Council, IOOC, until 2006), is still defining new criteria for distinguishing virgin olive oils from pomace olive oil with consideration of different olive oil producers worldwide (3).

Recently, the outbreak of genomics and especially deposition of several sequences of olive genome on NCBI (National Center for Biotechnology Information) database (including 83019 nucleotides, 9959 ESTs and 26 GSS hints for Olea europaea L. by 10/04/2013) have offered a new perspective for researchers to perform DNA-based analysis involving olive cultivar identification and olive oil authentication especially for protection of certified brands such as PDO (Protected Designation of Origin), PGI (Protected Geographical Indication) and TSG (Traditional Speciality Guaranteed) (4).

The genomic analysis of olive oil involved two main obstacles, which were complications with; extraction of DNA from an oily matrix and selection of appropriate molecular markers that can provide trustable results. Different techniques (CTAB, silica extraction, hydroxyapa-

Article type: Editorial; Received: 01 Apr 2013; Accepted: 26 Apr 2013; Epub: 16 May 2013, Ppub: June 2013

-Implication for health policy/practice/research/medical education:

The implication of this article is that olive oil genetic traceability could recognize the genetic background of olive oil aiming to prove the purity of this valuable food against adulteration with any extraneous material and even olive oil of lower cost.

Please cite this paper as:

Rabiei Z. Genomics and olive oil: Past and current challenges in olive oil adulteration. Iran J Biotech. 2013:11(2): 72-3. DOI: 10.5812/ ijb.11880

Copyright @ ( 2013, National Institute of Genetic Engineering and Biotechnology; Published by Kowsar Corp.

This is an Open Access article distributed under the terms of the Creative Commons Attribution License (http://creativecommons.org/licenses/by/3.0), which permits unrestricted use, distribution, and reproduction in any medium, provided the original work is properly cited. 
tite, magnetic beads, spun column, and Commercial kits) have proved to retain DNA from olive oil. Despite this, it has been shown that DNA isolated from olive oil could be damaged by oxidation reactions, when stored $(5,6)$. If the DNA is damaged, it could not be properly accessible for the DNA polymerase, which stalls at the sites of damage and the reaction may be interrupted or the reaction may end with an erratic amplicon size. In other words, DNA of low quality would potentially lead to inconsistent and consequently inconclusive results. However, successful PCR amplification probably depends on the ability of the DNA extraction method and correct selection of molecular markers. Many studies in recent years have employed AFLP (Amplified Fragment Length Polymorphism), RAPD (Random Amplification of Polymorphic DNA), ISSR (Inter-Simple Sequence Repeat), SSRs (Simple Sequence Repeats), LDR/UA (Ligation Detection Reaction Coupled to Universal Array), qRT-PCR (quantitative real-time PCR), SNPs (Single-Nucleotide Polymorphisms), CE-SSCP (Capillary Electrophoresis-Based-Single Strand Conformational Polymorphism), and DNA barcoding are genetic tools for production of a reliable platform to identify the cultivars formulating an olive oil. A modern DNA fingerprinting method termed, the "Identity Card" can also be used for an unequivocal identification of highly prized olive oil (7). Furthermore, special SNPs, single base extensions (SBE) have successfully identified the admixture of olive oil and hazelnut oil using chloroplast DNA. Therefore, chloroplast and mitochondrial sequences are supposed to provide greater benefits than nuclear sequences since including a higher gene copy number per cell, is especially beneficial for refined oil authentication.

Besides the use of a biotechnological approach in in- vestigation of olive oil authenticity by food-biotechnologists, the new horizon in chemical analysis could also be promising in this context; through the applications of nano-liquid chromatography and capillary electromigration techniques as well as omics technologies (and even foodomics, nutrigenomics and nutrigenetics).

\section{Authors' Contribution}

The entire manuscript was prepared by the author.

\section{Financial Disclosure}

There is no financial disclosure.

\section{References}

1. Rotondi A, Beghè D, Fabbri A, Ganino T. Olive oil traceability by means of chemical and sensory analyses: A comparison with SSR biomolecular profiles. Food Chem. 2011;129(4):1825-31

2. Araghipour N, Colineau J, Koot A, Akkermans W, Rojas JMM, Beauchamp J, et al. Geographical origin classification of olive oils by PTR-MS. Food Chemistry. 2008;108(1):374-383

3. Rabiei Z, Tahmasebi Enferadi S, Boskou D. Traceability of Origin and Authenticity of Olive Oil. In: Boskou D. (ed.) Olive Oil - Constituents, Quality, Health Properties and Bioconversions. In: Rabiei Z, Tahmasebi Enferadi S, Boskou D, editors.Rijeka: InTech.2011. p.163-184

4. Rabiei Z, Tahmasebi Enferadi S, Saidi A, Patui S, Vannozzi GP. SSRs (Simple Sequence Repeats) amplification: a tool to survey the genetic background of olive oils. Iran J Biotech. 2010;8(1):24-31

5. Bjelland S, Seeberg E. Mutagenicity, toxicity and repair of DNA base damage induced by oxidation. Mutat Res. 2003;531(1-2):37-80

6. Pafundo S, Busconi M, Agrimonti C, Fogher C, Marmiroli N. Storage-time effects on olive oil DNA assessed by Amplified Fragments Length Polymorphisms. Food Chem. 2010;123(3):787-93

7. Agrimonti C, Vietina M, Pafundo S, Marmiroli N. The use of food genomics to ensure the traceability of olive oil. Trends in Food Science \& Technology. 2011;22: 237-244 